\title{
SIMULTANEOUS DETERMINATION OF NON-STEROIDAL ANTI-INFLAMMATORY DRUGS IN PHARMACEUTICAL FORMULATIONS AND HUMAN SERUM BY REVERSED PHASE HIGH PERFORMANCE LIQUID CHROMATOGRAPHY
}

\section{Muhammad Nawaz}

Department of Chemistry, University of Karachi, Karachi-75270, Pakistan

Recebido em 8/7/11; aceito em 29/11/11; publicado na web em 23/1/12

\begin{abstract}
A rapid and sensitive method using high performance liquid chromatography has been developed and validated for the simultaneous determination of non-steroidal anti-inflammatory drugs (NSAIDs) in pharmaceutical formulations and human serum. Six NSAIDs including: naproxen sodium, diclofenac sodium, meloxicam, flurbiprofen, tiaprofenic and mefenamic acid were analyzed simultaneously in presence of ibuprofen as internal standard on Mediterranea $\mathrm{C}_{18}(5 \mu \mathrm{m}, 250 \times 0.46 \mathrm{~mm})$ column. Mobile phase comprised of methanol: acetonitrile: $\mathrm{H}_{2} \mathrm{O}(60: 20: 20, \mathrm{v} / \mathrm{v} ; \mathrm{pH} 3.35)$ and pumped at a flow rate of $1 \mathrm{~mL} \mathrm{~min}^{-1}$ using $265 \mathrm{~nm} \mathrm{UV}$ detection. The method was linear over a concentration range of $0.25-50 \mu \mathrm{gL}^{-1}\left(\mathrm{r}^{2}=0.9999\right)$.
\end{abstract}

Keywords: NSAIDs; serum; reversed phase high performance liquid chromatography.

\section{INTRODUCTION}

Non-steroidal anti-inflammatory drugs (NSAIDs) (Figure 1) have analgesics, antipyretics and anti-inflammatory activities and are widely used in the treatment of acute and chronic pain, osteoarthritis, rheumatoid arthritis and related conditions. The pharmacological actions of NSAIDs are related to inhibition of cyclooxygenase (COX), a<smiles>Cc1cnc(NC(=O)C2=C(O)c3ccccc3S(=O)(=O)N2C)s1</smiles>

Meloxicam<smiles>Cc1cccc(Nc2ccccc2C(=O)O)c1C</smiles>

Mefenamic acid<smiles>C[C@H](C(=O)O)c1ccc(C(=O)c2ccccc2)s1</smiles>

Tiaprofenic acid<smiles>CC(C)Cc1ccc(C(C)C(=O)O)cc1</smiles>

Ibuprofen (internal standard)

Figure 1. Chemical structures of non-steroidal anti-inflammatory drugs

e-mail: nawwaz@gmail.com key enzyme of prostaglandin biosynthesis at the site of inflammation. The simultaneous measurement of these NSAIDs concentrations in biological samples is required in clinical and toxicological screening, pharmacokinetic studies, as well as in therapeutic monitoring. Furthermore, it is also very important to precisely quantify these NSAIDs in pharmaceutical formulations for quality control. ${ }^{1}$

Until now, a variety of chromatographic methods have been proposed for the determination of NSAIDs in pharmaceutical formulations and biological fluids, by gas chromatography, ${ }^{2-4}$ spectrofluorometry, ${ }^{5}$ high performance liquid chromatography ${ }^{6-17}$ and capillary electrophoresis. ${ }^{18}$

Generally, it is impossible that one patient would be prescribed for more than one kind of NSAIDs at the same time; however simultaneous determination of these drugs is useful in pharmaceutical routine analysis and biological samples.

This paper reports the simultaneous determination of NSAIDs in pharmaceutical formulations and human serum. It is precise, accurate and rapid method.

\section{EXPERIMENTAL}

\section{Materials and reagents}

Pure tiaprofenic acid was obtained from Aventis Pharma (Pvt) Ltd, meloxicam from AGP (Pvt) Ltd, diclofenac sodium, flurbiprofen, ibuprofen and naproxen sodium from Pharmevo (Pvt) Ltd. Dosages form of Tiaprofenic acid (Surgam ${ }^{\circledR} 300 \mathrm{mg}$ ) diclofenac sodium (Voltral ${ }^{\circledR} 50 \mathrm{mg}$ ) flurbiprofen (Synalgo ${ }^{\circledR} 100 \mathrm{mg}$ ), meloxicam (Melfax ${ }^{\circledR} 15 \mathrm{mg}$ ) and mefenamic acid (Ponstan ${ }^{\circledR} 250 \mathrm{mg}$ ) were purchased from local market. Methanol and acetonitrile (analytical grade) were purchased from Tedia, USA. Deionized water was used to prepare a mobile phase.

\section{Instrumentation and chromatographic conditions}

The development of the method and validation of the work was performed on a liquid chromatographic system consisting of Shimadzu model LC-10AT VP pump with a SPD-10AT VP, variable wavelength UV-Visible detector. Chromatographic system was integrated via Shimadzu model CBM-102 Communication Bus Module 
to a Pentium-4 PC. Analysis was conducted on a Mediterranea C18 (Teknokroma ${ }^{\circledR}$, Karachi, Pakistan) $(5 \mu \mathrm{m}, 250$ x $0.46 \mathrm{~mm})$ column, mobile phase consisted of methanol: acetonitrile: $\mathrm{H}_{2} \mathrm{O}$ (60:20:20, $\mathrm{v} / \mathrm{v}$ ) and $\mathrm{pH}$ was adjusted to 3.35 (apparent $\mathrm{pH}$ ) with orthophosphoric acid. Mobile phase was filtered daily using $0.45 \mu \mathrm{m}$ membrane filter (Millipore, Germany) and degassed in an ultrasonic bath. The samples were introduced through a rheodyne injector valve with a 20-mL sample loop. Assays were performed at ambient temperature at a flow rate of $1 \mathrm{~mL} \mathrm{~min}-1$ and detection at $265 \mathrm{~nm}$.

\section{Preparation of standard solutions}

Standard solution of non-steroidal anti-inflammatory drugs and internal standard $\left(100 \mu \mathrm{g} \mathrm{mL}^{-1}\right)$ were prepared by dissolving them in methanol. Internal standard solution was further diluted with methanol to give concentration $50 \mu \mathrm{g} \mathrm{mL} \mathrm{m}^{-1}$.

\section{Preparation of calibration curves}

Appropriate dilution of standard solution $(100 \mu \mathrm{g} \mathrm{mL}-1)$ of nonsteroidal anti-inflammatory drugs were made using methanol to obtain solution of concentration of $0.25,1.0,2.50,5.0,12.50,25.0$ and $50.0 \mu \mathrm{g} \mathrm{mL}^{-1}$. A correlation between peak area and concentration $0.25-50 \mu \mathrm{g} \mathrm{mL}^{-1}$ of non-steroidal anti-inflammatory drugs were established and calibration curves were obtained.

\section{Limit of detection and quantification (LOD and LOQ)}

The limit of detection is the lowest quantity of analyte in any sample which can be detected but cannot be quantified where as the quantitation limit of any analytical procedure is the lowest amount of analyte in a sample which can be quantitatively analyzed with suitable precision and accuracy. The equation used to calculate LOD and LOQ are:

$$
\mathrm{LOD}=3.3 \mathrm{o}^{\circ} / S \text { and } \mathrm{LOQ}=10 \mathrm{\%} / S
$$

$\sigma=$ standard deviation of the lowest standard concentration, $S=$ slope of the standard curve.

\section{Precision and accuracy}

The precision of proposed method was evaluated through intra-day (repeatability) and inter-day (intermediate precision) at concentration of $0.25,2.50$ and $12.50 \mu \mathrm{g} \mathrm{mL} \mathrm{m}^{-1}$. Three replicates were made for intra- and inter-day study. The precision is expressed as percentage relative standard deviation (\% RSD). To evaluate the accuracy of the proposed method, recovery tests for all analytes were performed by adding known amounts of standard solutions to samples followed by analysis using proposed method. Accuracy was expressed as percentage recovery and determined at three concentration levels $\left(0.25,2.50\right.$ and $\left.12.50 \mu \mathrm{g} \mathrm{mL}^{-1}\right)$. Three replicates were made for accuracy study.

\section{Selectivity}

The selectivity of the method was evaluated by analyzing blank drug-free serum samples obtained from healthy volunteer and spiked serum samples. The probable interferences from endogenous substances were assessed by observing the chromatograms of blank and spiked serum samples. Non-steroidal anti-inflammatory drugs pharmaceutical formulations were also analyzed and compared with the standard chromatograms of drugs for excipients interference.

\section{Dosage analysis}

The contents of 20 tablets of tiaprofenic acid (Surgam $\left.{ }^{\circledR} 300 \mathrm{mg}\right)$ diclofenac sodium (Voltral ${ }^{\circledR} 50 \mathrm{mg}$ ) flurbiprofen (Synalgo ${ }^{\circledR} 100 \mathrm{mg}$ ), meloxicam (Melfax ${ }^{\circledR} 15 \mathrm{mg}$ ) and mefenamic acid (Ponstan ${ }^{\circledR} 250 \mathrm{mg}$ ) were weighed and finely grounded. A mass of powder equivalent to the average mass of a tablet was transferred to volumetric flasks with methanol. Solutions were sonicated in ultrasonic bath for $10 \mathrm{~min}$ and then diluted to volume with methanol. These primary stock solutions were filtered through Whatman filter paper and the filtrates were further diluted suitably to prepare a secondary stock solution. Aliquots of the secondary stock solution were diluted to a concentration of $0.25,2.50$ and $12.50 \mu \mathrm{g} \mathrm{mL}^{-1}$ and the samples were analyzed using above mentioned chromatographic conditions.

\section{Serum drug analysis}

The recoveries of non-steroidal anti-inflammatory drugs from pooled human serum were determined by the stated chromatographic conditions. Multiple blood samples $(10 \mathrm{~mL})$ of 15 healthy non-smoker volunteers (age ranging from 21-25 years), not taking any other medicaments were collected in glass tubes. $10 \mathrm{~mL}$ of acetonitrile was then added to each serum samples to precipitate the proteins. After $15 \mathrm{~min}$ of centrifugation at $3000 \mathrm{rpm}$, all the upper layers from the serum samples were put together to receive a representative pool of human serum samples. This pool of serum samples was mixed with NSAIDs and internal standard in 1:1:1 ratio, filtered and analyzed. ${ }^{19,20}$

\section{RESULTS AND DISCUSSION}

Isocratic-mode of HPLC with UV detection was developed for the determination of non-steroidal anti-inflammatory drugs in pharmaceutical formulations and in human serum. Serum deproteination for the determination of drugs is commonly accepted as the simplest methods as compared liquid-liquid extraction or solid-phase extraction from plasma samples and usually have high reproducibility.

\section{Optimization of chromatographic conditions}

In order to achieve a suitable separation of analytes from endogenous compounds of serum matrix, the isocratic elution mode was chosen. The method was optimized by variation in $\mathrm{pH}$ of the mobile phase and the percentage and nature of the organic modifier (acetonitrile or methanol).

Firstly, an attempt was made regarding the composition of the mobile phase and $\mathrm{pH}$. Proportions of water higher than $20 \%$ gave rise to chromatographic signals which suffered major frontings. Higher percentage of methanol than $60 \%$ results in long retention time and $20 \%$ of acetonitrile was found suitable in mobile phase. When percentage of acetonitrile was increased in mobile phase peaks were emerged. Chromatographic peaks obtained at $\mathrm{pH} 3.35$ were sharp (Figure 2) than those observed at $\mathrm{pH} 4$ and also absorbance of endogenous components of serum was lower at $\mathrm{pH} 3.35$ (Figure 3a and $3 \mathrm{~b}$ ). So mobile phase consisting of methanol:acetonitrile: $\mathrm{H}_{2} \mathrm{O}$ (60:20:20, v/v) and pH 3.35 was optimal for the separation of non-steroidal anti-inflammatory drugs and it provides high sensitivity.

The system suitability was performed by studying the parameters which include column efficiency or theoretical plates $(\mathrm{N})$, resolution $(\mathrm{R})$, peak asymmetry or tailing factor $\left(\mathrm{A}_{\mathrm{S}}\right)$ and capacity factor $(\mathrm{k})$. The low value of peak asymmetry or tailing factor and high values of column efficiency or theoretical plates, resolution and capacity factor indicated the suitability and proper selection of mobile phase. These parameters are presented in Table 1. 


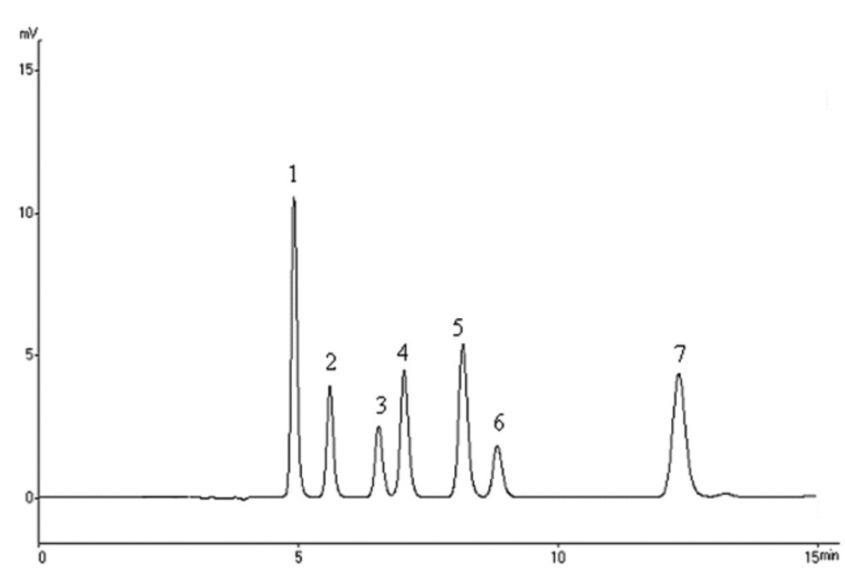

Figure 2. Chromatogram of non-steroidal anti-inflammatory drugs in the presence of ibuprofen as internal standard: (1) tiaprofenic acid, (2) meloxicam, (3) naproxen sodium, (4) flurbiprofen, (5) diclofenac sodium, (6) ibuprofen, (7) mefenamic acid

Table 1. Chromatographic data for separation of NSAIDs on a Mediterranea $\mathrm{C}_{18}$ column under the optimum separation conditions

\begin{tabular}{lcccc}
\hline Analytes & $\mathrm{K}^{\mathrm{a}}$ & $\mathrm{As}^{\mathrm{b}}$ & $\mathrm{N}^{\mathrm{c}}$ & $\mathrm{Rs}^{\mathrm{d}}$ \\
\hline Tiaprofenic & 1.17 & 1.19 & 9088 & 10.15 \\
Meloxicam & 1.47 & 1.14 & 9308 & 3.17 \\
Naproxen & 1.89 & 1.17 & 9136 & 3.73 \\
Flurbiprofen & 2.11 & 1.12 & 9789 & 1.77 \\
Diclofenac & 2.61 & 1.13 & 10699 & 3.78 \\
Mefenamic & 4.45 & 1.13 & 11364 & 8.79 \\
\hline
\end{tabular}

acapacity factor; ${ }^{\mathrm{b}}$ peak asymmetry; 'number of theoretical plates, ${ }^{\mathrm{d}}$ resolution

Method development and validation was carried out according to $\mathrm{ICH}$ validation guidelines. ${ }^{21}$

\section{Linearity and sensitivity}

The linearity of the method was evaluated by injecting six replicate of different concentrations. Linearity was observed in the concentration range of $0.25-50 \mu \mathrm{g} \mathrm{mL} \mathrm{m}^{-1}$. For the determination of linearity, standard calibration curve was used. The statistical results of the linearity, LOD and LOQ values are given in Table 2.

\section{Precision and accuracy}

The precision was expressed as percentage relative standard deviation (\% RSD) and it ranged in $0.02-2.76 \%$ and $0.01-1.54 \%$ for (a)

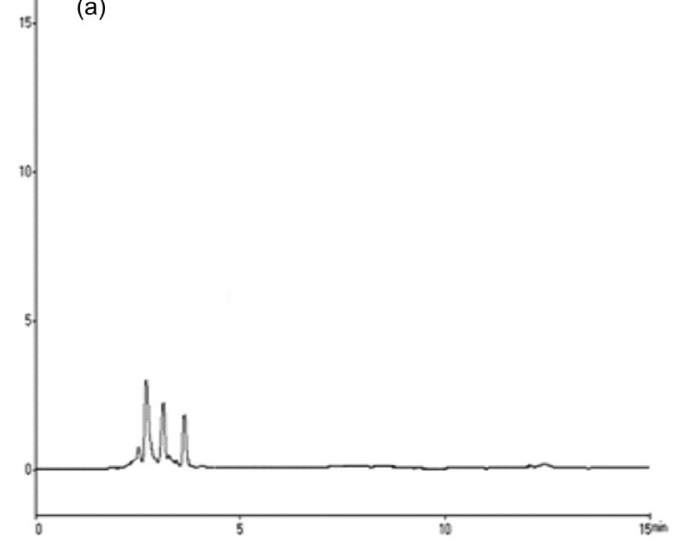

(b)

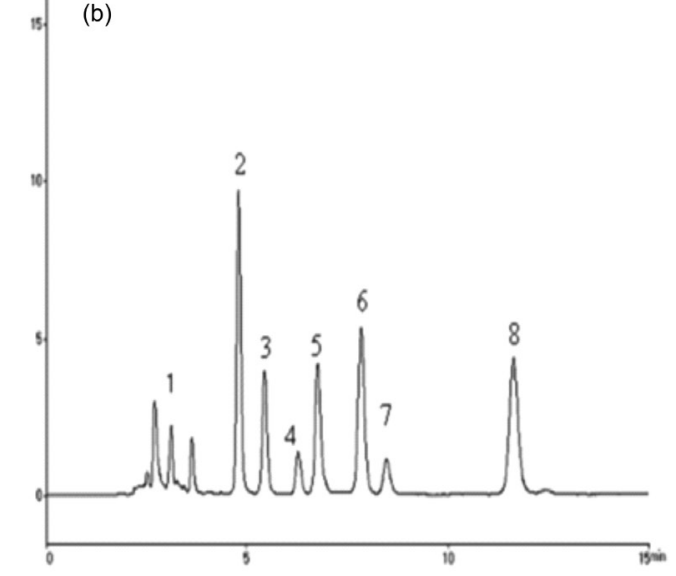

Figure 3. Chromatograms of: (a) drug-free human serum; (b) non-steroidal anti-inflammatory drugs spiked in human serum: (1) serum peaks, (2) tiaprofenic acid, (3) meloxicam, (4) naproxen sodium, (5) flurbiprofen, (6) diclofenac sodium, (7) ibuprofen, (8) mefenamic acid

intra- and inter-day respectively in pharmaceutical formulations while in serum it was less than $3 \%$ (Table 3). Accuracy was expressed as percentage recovery and it was determined at three concentration levels. Three replicates were made for accuracy study, intra- and inter-day percentage recoveries from pharmaceutical formulations ranged in $98-102 \%$ and $97-102 \%$, respectively. Recoveries from human serum ranged in $97-101 \%$ (Table 4).

\section{Selectivity}

The chromatograms obtained from blank, spiked serum samples and pharmaceutical formulations were identical with that obtained chromatogram from standard solution of NSAIDs. There was no peak

Table 2. Calibration curves and limit of detection and quantification of non-steroidal anti-inflammatory drugs in pharmaceutical formulations

\begin{tabular}{|c|c|c|c|c|c|}
\hline \multirow{2}{*}{ Analytes } & \multirow{2}{*}{$\begin{array}{l}\text { Concentration } \\
\text { range }\left(\mu \mathrm{gLL}^{-1}\right)\end{array}$} & \multirow{2}{*}{ Regression equation } & $\mathrm{r}^{2 \mathrm{a}}$ & $\mathrm{LOD}^{\mathrm{b}}$ & $\mathrm{LOQ}^{\mathrm{c}}$ \\
\hline & & & \multicolumn{3}{|c|}{$\left(\mu \mathrm{g} \mathrm{mL}^{-1}\right)$} \\
\hline Tiaprofenic & $0.25-50$ & $y=1635.00 x+943.58$ & 0.9995 & 0.004 & 0.013 \\
\hline Meloxicam & $0.5-50$ & $y=681.90 x+380.18$ & 0.9997 & 0.005 & 0.015 \\
\hline Naproxen & $1.0-50$ & $y=510.37 x+354.13$ & 0.9996 & 0.007 & 0.023 \\
\hline Flurbiprofen & $0.5-50$ & $y=966.21 x+535.10$ & 0.9996 & 0.005 & 0.016 \\
\hline Diclofenac & $0.25-50$ & $y=1286.40 x+479.23$ & 0.9998 & 0.003 & 0.009 \\
\hline Mefenamic & $0.5-50$ & $y=1518.20 x+854.37$ & 0.9995 & 0.002 & 0.007 \\
\hline
\end{tabular}

${ }^{\mathrm{a}}$ Correlation of coefficient, ${ }^{\mathrm{b}}$ limit of detection $(\mathrm{S} / \mathrm{N}=3)$, ${ }^{\mathrm{c}}$ limit of quantification $(\mathrm{S} / \mathrm{N}=10)$ 
Table 3. Accuracy and precision of non-steroidal anti-inflammatory drugs in pharmaceutical formulations

\begin{tabular}{|c|c|c|c|c|c|c|}
\hline \multirow{2}{*}{$\begin{array}{l}{ }^{\mathrm{a} C o n c} \text {. added } \\
\left(\mu \mathrm{g} \mathrm{mL} \mathrm{L}^{-1}\right)\end{array}$} & \multirow{2}{*}{$\begin{array}{c}\text { Found } \\
\left(\mu \mathrm{g} \mathrm{mL}^{-1}\right)\end{array}$} & \multicolumn{2}{|c|}{ Intra-day } & \multirow{2}{*}{$\begin{array}{c}\text { Found } \\
\left(\mu \mathrm{g} \mathrm{mL}^{-1}\right)\end{array}$} & \multicolumn{2}{|c|}{ Inter-day } \\
\hline & & $\mathrm{RSD} \%^{\mathrm{b}}$ & $\%$ Rec. $^{\mathrm{c}}$ & & $\mathrm{RSD} \%$ & $\%$ Rec. \\
\hline \multicolumn{7}{|l|}{ Tiaprofenic } \\
\hline 0.25 & 0.26 & 0.94 & 100 & 0.25 & 1.00 & 98 \\
\hline 2.50 & 2.49 & 1.97 & 100 & 2.50 & 3.86 & 100 \\
\hline 12.50 & 12.50 & 1.26 & 100 & 12.51 & 0.11 & 100 \\
\hline \multicolumn{7}{|c|}{ Diclofenac sodium } \\
\hline 0.25 & 0.25 & 1.23 & 101 & 0.25 & 0.99 & 99 \\
\hline 2.50 & 2.56 & 0.65 & 102 & 2.50 & 0.18 & 100 \\
\hline 12.50 & 12.46 & 1.25 & 100 & 12.49 & 0.05 & 100 \\
\hline \multicolumn{7}{|l|}{ Flurbiprofen } \\
\hline 0.50 & 0.49 & 1.75 & 98 & 0.51 & 0.77 & 102 \\
\hline 2.50 & 2.51 & 0.34 & 100 & 2.50 & 0.29 & 100 \\
\hline 12.0 & 12.5 & 1.28 & 100 & 12.51 & 0.06 & 100 \\
\hline \multicolumn{7}{|c|}{ Mefenamic acid } \\
\hline 0.25 & 0.24 & 1.23 & 97 & 0.25 & 1.20 & 98 \\
\hline 2.50 & 2.49 & 0.13 & 100 & 2.50 & 0.10 & 100 \\
\hline 12.50 & 12.49 & 1.53 & 100 & 12.50 & 0.01 & 100 \\
\hline \multicolumn{7}{|l|}{ Meloxicam } \\
\hline 0.50 & 0.52 & 0.14 & 102 & 0.49 & 1.54 & 97 \\
\hline 2.50 & 2.51 & 0.52 & 100 & 2.49 & 0.61 & 100 \\
\hline 12.50 & 12.48 & 2.76 & 100 & 12.48 & 0.04 & 100 \\
\hline \multicolumn{7}{|l|}{ Naproxen } \\
\hline 1.00 & 0.98 & 0.79 & 98 & 1.00 & 1.00 & 99 \\
\hline 2.50 & 2.56 & 3.22 & 102 & 2.49 & 5.10 & 100 \\
\hline 12.50 & 12.49 & 0.21 & 100 & 12.49 & 1.12 & 100 \\
\hline
\end{tabular}

${ }^{\mathrm{a}}$ Concentration, ${ }^{\mathrm{b}}$ relative standard deviation, ${ }^{\mathrm{c}} \%$ recovery

Table 4. Accuracy and precision of non-steroidal anti-inflammatory drugs in human serum

\begin{tabular}{|c|c|c|c|c|}
\hline \multirow{3}{*}{$\begin{array}{l}\text { Conc. added } \\
\left(\mu \mathrm{g} \mathrm{mL} L^{-1}\right)\end{array}$} & \multirow{3}{*}{$\begin{array}{l}\text { Found } \\
\left(\mu \mathrm{g} \mathrm{mL} L^{-1}\right)\end{array}$} & \multirow{3}{*}{$\%$ recovery } & \multicolumn{2}{|c|}{ Precision } \\
\hline & & & Intra-day & Inter-day \\
\hline & & & $\mathrm{RSD} \%$ & RSD \% \\
\hline \multicolumn{5}{|l|}{ Tiaprofenic } \\
\hline 0.25 & 0.24 & 97 & 1.02 & 0.95 \\
\hline 2.50 & 2.47 & 99 & 0.97 & 1.23 \\
\hline 12.50 & 12.44 & 100 & 2.01 & 1.65 \\
\hline \multicolumn{5}{|l|}{ Diclofenac } \\
\hline 0.25 & 0.26 & 98 & 1.14 & 2.11 \\
\hline 2.50 & 2.48 & 99 & 2.70 & 2.10 \\
\hline 12.50 & 12.49 & 100 & 1.05 & 0.98 \\
\hline \multicolumn{5}{|l|}{ Flurbiprofen } \\
\hline 0.50 & 0.50 & 98 & 1.02 & 0.85 \\
\hline 2.50 & 2.52 & 101 & 0.46 & 1.01 \\
\hline 12.50 & 11.48 & 100 & 1.23 & 3.86 \\
\hline \multicolumn{5}{|l|}{ Mefenamic } \\
\hline 0.25 & 0.25 & 102 & 0.52 & 0.76 \\
\hline 2.50 & 2.48 & 99 & 0.20 & 0.89 \\
\hline 12.50 & 12.49 & 100 & 2.76 & 1.24 \\
\hline \multicolumn{5}{|l|}{ Meloxicam } \\
\hline 0.50 & 0.49 & 98 & 0.39 & 0.41 \\
\hline 2.50 & 2.49 & 100 & 1.02 & 1.12 \\
\hline 12.50 & 12.49 & 100 & 0.15 & 0.89 \\
\hline \multicolumn{5}{|l|}{ Naproxen } \\
\hline 1.00 & 1.06 & 101 & 0.75 & 0.65 \\
\hline 2.50 & 2.47 & 101 & 1.96 & 1.26 \\
\hline 12.50 & 12.50 & 100 & 1.23 & 0.92 \\
\hline
\end{tabular}

observed when the analysis of placebo solution of NSAIDs were done. In addition, peak purity index of all analytes were investigated and found to be $>0.999$. Thus method demonstrated good resolution and found to be free of interferences.

\section{Ruggedness}

Method ruggedness was evaluated by two analysts performing assay on separate lots of non-steroidal anti-inflammatory drugs. Each analyst prepared samples in triplicate and used separate instruments, reagents, diluent and mobile phase solutions. Relative standard deviation $(n=3)$ of for all of the samples for each lot was less than $2.0 \%$ indicating acceptable robustness. The method did not show any notable deviation in results from acceptable limits.

\section{CONCLUSIONS}

The proposed method using reversed phase high performance liquid chromatography was found to be suitable for simultaneous determination of non-steroidal anti-inflammatory drugs in pharmaceutical formulations and human serum. The detector response was found to be linear over a wide concentration range. Results are accurate and precise and are confirmed by the statistical parameters. The precision and accuracy of the method are well within the limits required for bioanalytical assays. The lower limit of quantification permitted the use of the method for pharmacokinetic studies.

\section{ACKNOWLEDGEMENT}

The author is thankful to his family members for their financial support. 


\section{REFERENCES}

1. Sun, Y.; Takaba, K.; Kido, H.; Nakashima, M. N.; Nakashima K.; J. Pharm. Biomed. Anal. 2003, 30, 1611.

2. Kim, K. R.; Yoon, H. R.; J. Chromatogr., B: Anal. Technol. Biomed. Life Sci. 1996, 682, 55.

3. Way, B. A.; Wilhite, T. R.; Smith, C. H.; Lande, M.; J. Clin. Lab. Anal. 1997, 11, 336 .

4. El Haj, B. M.; Al Ainri, A. M.; Hassan, M. H.; Bin Khadem, R. K.; Marzouq, M. S.; Forens. Sci. Int. 1999, 105, 141.

5. Damiani, P. C.; Bearzotti, M.; Cabezon, M. A.; J. Pham. Biomed. Anal. 2001, 25, 679 .

6. Jedziniak, P.; Szprengier-Juszkiewicz, T.; Małgorzata, O.; Żmudzki J.; Anal. Chim. Acta 2010, 672, 85.

7. Aguilar-Arteaga, K.; Rodriguez, J. A.; Miranda, J. M.; Medina, J.; Barrado, E.; Talanta 2010, 80,1152.

8. Madni, A. U.; Ahmad, M.; Akhtar, N.; Usman, M.; World Acad. Sci. Engin. Technol. 2009, 55, 158.

9. Ibrahim, H.; Boyer, A.; Bouajila, J.; Couderc, F.; Nepveu, F.; J. Chromatogr., B: Anal. Technol. Biomed Life Sci. 2007, 857, 59.

10. Panusa, A.; Multari, A.; Incarnato, G.; Gangliardi, L.; J. Pharm. Biomed. Anal. 2007, 43, 1221.

11. Canaparo, R.; Muntoni, E.; Zara, G. P.; Della, P. C.; Berno, E.; Costa, M.; Eandi, M.; Biomed. Chromatogr. 2000, 14, 219.
12. Arcelloni, C.; Lanzi, R.; Pedercini, S.; Molteni, G.; Fermo, I.; Pontiroli, A.; Paroni, R.; J. Chromatogr., B: Anal. Technol. Biomed Life Sci. 2001, 763,195 .

13. Mikami, E.; Goto, T.; Ohno, T.; Matsumoto, H.; Inagaki, K.; Ishihara, H.; Nishida, M.; J. Chromatogr., B: Anal. Technol. Biomed Life Sci. 2000, 744, 81

14. Martin, M. J.; Pablos, F.; Gonzalez, A. G.; Talanta 1999, 49, 453.

15. Hirai, T.; Matsumoto, S.; Kishi, I.; J. Chromatogr., B: Anal. Technol. Biomed Life Sci. 1997, 692, 375.

16. Niopas, I.; Mamzoridi, K.; J. Chromatogr., B: Anal. Technol. Biomed Life Sci. 1994, 656, 447.

17. Kazemifard, A. G.; Moore, D. E.; J. Chromatogr., B: Anal. Technol. Biomed Life Sci. 1990, 533, 125.

18. Heitmeier, S.; Blaschke, G.; J. Chromatogr., B: Anal. Technol. Biomed Life Sci. 1999, 721, 109.

19. Arayne, M. S.; Sultana, N.; Nawaz, M.; J. Anal. Chem. 2008, 63, 881.

20. Arayne, M. S.; Sultana, N.; Agha, Z. M.; Farhan, A. S.; J. Chil. Chem. Soc. 2010, 55, 156.

21. The European Agency for the Evaluation of Medical Products; $I C H$ TopicQ2B Note for Guidance on Validation of Analytical Procedures: Methodology, GPMP/ICH/281/95, 1996. 